
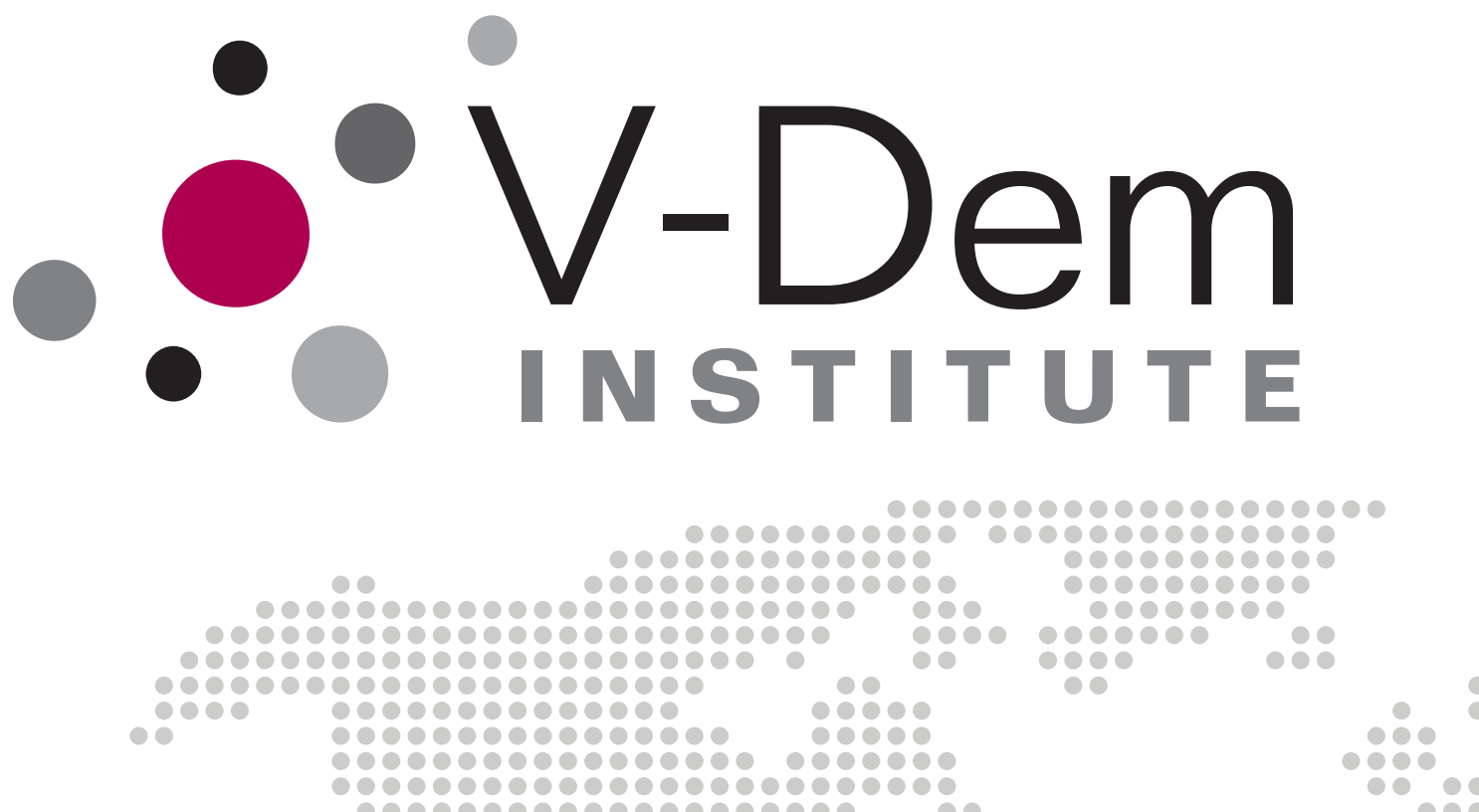

$$
100
$$

909098

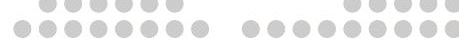
1000 $0090900009000 \mathrm{c}$ $1000000000000000 \mathrm{c}$  -

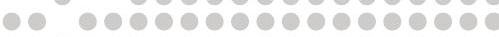

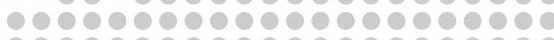
100000000000000000 b000000000000000 000000000000

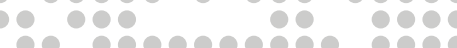
100

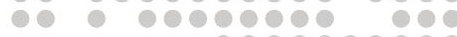

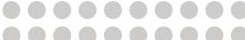

When Democracy has a Fever: States of Emergency as a Symptom and Accelerator of Autocratization

Anna Lührmann Bryan Rooney
00000000

0000000

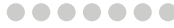

100000

10000

000

000

10

10

80

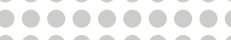

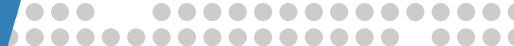

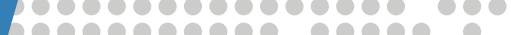

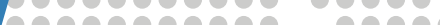

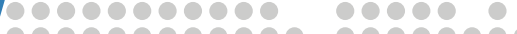

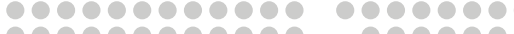


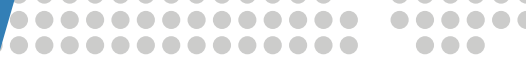

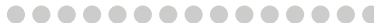
\begin{tabular}{l}
10000000000000000000 \\
\hline
\end{tabular} 00000000000000000000 2000000000000000000

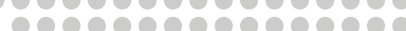

P0000000000000

100000000000

0000000000

00090000900

000000000

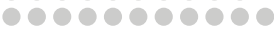

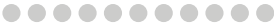

69000000000

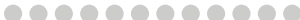

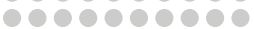

6roberó

00000000

0000000

100000

000000

1000

100

10

C 
Varieties of Democracy ( $\mathbf{V}-\mathbf{D e m})$ is a new approach to conceptualization and measurement of democracy. The headquarters - the V-Dem Institute - is based at the University of Gothenburg with 17 staff. The project includes a worldwide team with six Principal Investigators, 14 Project Managers, 30 Regional Managers, 170 Country Coordinators, Research Assistants, and 3,000 Country Experts. The V-Dem project is one of the largest ever social science research-oriented data collection programs.

Please address comments and/or queries for information to:

V-Dem Institute

Department of Political Science

University of Gothenburg

Sprängkullsgatan 19, PO Box 711

SE 40530 Gothenburg

Sweden

E-mail: contact@v-dem.net

V-Dem Working Papers are available in electronic format at www.v-dem.net. Copyright (c) 2019 by the authors. All rights reserved. 


\section{When Democracy has a Fever: States of Emergency as a Symptom and Accelerator of Autocratization*}

\author{
Anna Lührmann \\ $V$-Dem Institute
}

anna.luehrmann@v-dem.net

\author{
Bryan Rooney \\ Carlos III-Juan March Institute of Social Sciences \\ brooney@clio.uc3m.es
}

${ }^{*}$ This research was supported by Vetenskapsradet [grant number 2018-016114], PI: Anna Luehrmann and European Research Council, Grant 724191, PI: Staffan I. Lindberg, V-Dem Institute, University of Gothenburg, Sweden as well as by internal grants from the Vice-Chancellors office, the Dean of the College of Social Sciences, and the Department of Political Science at University of Gothenburg. We are grateful for Philipp Toenjes' and Sandra Grahn's skillful research assistance. 


\begin{abstract}
States of emergency grant chief executives the power to circumvent democratic constraints in order to combat existential threats. As such they are ideal tools to erode democratic institutions while maintaining the illusion of constitutional legitimacy. Therefore, it seems plausible that states of emergency are associated with a heightened risk of autocratization a decline in a regime's democratic attributes. Despite this link and the contemporary relevance of both autocratization and states of emergency, no prior study has empirically tested this relationship. This paper fills this gap using data on 60 democracies for 1974 to 2016 . We find that democracies are $59 \%$ more likely to erode under a state of emergency. Like a fever, states of emergency are a potential symptom of a seriously ill democracy and they may accelerate democratic decay.
\end{abstract}




\section{Introduction}

On February 15th, 2019, President Donald Trump declared a national emergency on the southern border of the United States in an effort to circumvent Congressional will regarding the construction of a border wall. Although this is the 59th declared national emergency under the National Emergencies Act, it's character has been challenged as out of line with previous practice, and his decision was met with fierce criticism. For instance, 58 ex-senior security officials have call this move "at odds with the overwhelming evidence in the public record, including the administrations own data and estimates." ${ }^{1}$ However, while such actions are uncommon in throughout US history, President Trump is not the first democratically elected leader to be challenged for his use of emergency powers.

On July 22, 2016, the Turkish president Recep Tayyip Erdogan and his government declared a state of emergency - the first in history to encompass the entire state (Cunningham \& Naylor 2016) - in an attempt to "root out the virus" responsible for the coup attempt a few days earlier (Lowen 2016). Under Article 119 of the Turkish Constitution of 1982, the President of the Republic and the Council of Ministers may declare a state of emergency in the event of "serious indications of widespread acts of violence aimed at the destruction of the free democratic order established by the Constitution or of fundamental rights and freedoms." Once an emergency has been declared, the President "may issue decrees having the force of law on matters necessitated by the state of emergency (Article 121)." Under these emergency powers, Erdogan and the Turkish government have jailed more than 40,000 people accused of plotting a failed coup, fired more than 140,000 people from their jobs, shut down 1,500 civil groups, and virtually removed freedom of the press by arresting journalists and closing independent media outlets (Kingsley 2017). Though the state of emergency was scheduled to last for three months, the state of emergency persisted until July 2018 over two full years - when Erdogan had won reelection. Through the use of his emergency

\footnotetext{
${ }^{1}$ cdn.cnn.com/cnn/2019/images/02/25/2019-2-21.final.national.emergency.decl.pdf
} 
powers, Erdogan has de-facto transformed Turkey into a presidential dictatorship (Esen \& Gumuscu 2017).

The extension of political power to the executive in times of real or manufactured crisis is not contained to the US or the Turkish case. Constitutions frequently allow the executive to centralize power when confronted by a heightened threat (Rossiter 1948, Ferejohn \& Pasquino 2004). From 1800 to 2012, 80 democracies adopted such provisions for the state of emergency - formal legal acts that dictate the shifting roles of state actors and institutions during times of international or domestic crisis. This accounts for over half of all democratic country-years during this time period. The descent of Turkey into dictatorship demonstrates how the effects of a state of emergency can be quite dramatic and long-lasting. However, outside an examination of early cases (Rossiter 1948), we know very little about the relationship of the state of exception to autocratization. This is a notable omission in the literature. Autocratization - the gradual or sudden decline of democratic regime attributes - is on the rise globally (Mechkova, Lührmann \& Lindberg 2017). It is therefore vital to understand better how autocratization unfolds and which factors foster the decline of democracy. States of emergency may well be a crucial piece in this puzzle. They present an opportunity for wanna-be dictators to assume more power under the veneer of constitutional legitimacy. Once in place, they give leaders - such as Erdogan - the power to mute dissent and centralize political authority. At the same time, chief excecutives with the intent to dismantle democracy can be considered more likely to invoke a state of emergency and - once it is in place - abuse the extraordinary powers that typically come with it. Like a fever, states of emergency are both a symptom and an accelerator of democratic decline. As a result, we expect that countries are likely affected by substantial autocratization when a state of emergency is declared as opposed to when not.

The purpose of this paper is to empirically assess this hypothesis with the help of regression analysis on 60 democracies from 1974-2016. Our dependent variable indicates whether 
or not a country is in undergoing a process of substantial autocratization based on Lhrmann and Lindberg (2018). Data on declared states of emergency comes from Hafner-Burton, Helfer and Fariss (2011) and the State Department's annual human rights reports. ${ }^{2}$ Our results suggests that countries with a state of emergency are indeed more likely to also undergo a periods of democratic decline. In fact, we find that democracies are $59 \%$ more likely to erode under a state of emergency than without.

We proceed as follows. First, we discuss the origins and application of states of emergency. We take specific note of how states of emergency empower executives. Then, we discuss the state of the art on the relationship between states of emergency and autocratization followed by the development of our theoretical argument. Subsequently we introduce our data sources and research design. The final sections discusses the empirical findings and conclusions.

\section{The Origins of the State of Exception}

The state of exception in modern states trace back to the Roman Republic, where in times of national emergency, the Roman consuls would nominate a dictator who had nearly absolute power to take action free from the standard political institutions (Rossiter 1948). Today, emergency provisions are common institutional features of democratic states with a variety of constitutional arrangements, designed to overcome restraints on necessary action during periods of national distress.

Scholars suggest that those who build the institutions within democracies view centralized executive power in wartime as a necessary evil, compromising some democratic principles to enhance national security in the event that a substantial or existential external threat arises (Rossiter 1948, Ferejohn \& Pasquino 2004). In order to properly study emergency provisions, we need to understand where they come from and how and why they are more

\footnotetext{
${ }^{2}$ https://www.state.gov/j/drl/rls/hrrpt/humanrightsreport/
} 
extensive in some cases than others. Though there are few direct accounts of the decision to adopt emergency provisions in modern states, historical accounts of constitution-making in democracies and considerations of factors that exacerbate emergencies suggest several factors that influence the decision to adopt emergency powers and the decision of how strong the executive must be to sufficiently handle an emergency situation. ${ }^{3}$

The first determinant of the provision of a state of emergency is the strength of the executive in times of peace. Leaders that face particularly strong domestic constraints on their actions during peacetime require greater freedom of action to overcome emergency situations. This should be especially true in the case of states with a strong separation of powers and complex governments. While such institutions are inherent in many modern democracies, the predominant example of such decision-making is the provision for dictatorship in the Roman Republic. As Rome had a complex constitutional system featuring an unparalleled division of administrative authority, as well as a great number of checks on executive action during times of peace, the Roman dictator had nearly absolute power to combat a national emergency (Rossiter 1948). Emergency powers historically result from the desire to break deadlock, and thus systems with a greater potential for institutional gridlock are more likely to allow for the provision of a state of emergency.

States often provide for a state of exception when the nation's standard democratic institutions have proven unable to combat domestic discord or internal strife. This is evident in the Venezuelan Constitution of 1961. Venezuela's constitutional framers, like those many in nascent democracies, had clear memories of the nation's previous experience with autocracy and had to consider its long history of domestic coups and military intervention in the government (Manrique 1988). Since democratic constitutions often allow emergency action to battle coup d'états and and civil discord, the provision of states of emergency exist when states have a history of domestic conflict. However, this internal discord is not limited to

\footnotetext{
${ }^{3}$ Rooney (Unpublished) examines these emergency provisions empirically.
} 
armed rebellion. States that suffer a large economic downturn during times of interstate or intrastate conflict realize this danger. Those who build democratic institutions may see centralization of political power as a way to protect an economy that is vulnerable in the event of a future crisis. Returning to the case of the Venezuelan Constitution of 1961, past economic and financial difficulties weighed as heavily on the minds of the nation's framers as Venezuela's history of domestic discord. Economic burdens during periods of emergency promoted a strong belief that Venezuelan leaders must have greater ability to guide their nation through times of crisis (Manrique 1988).

Framers of democratic institutions also grant emergency powers to the executive due to the high stakes of international conflict. States that have experienced a greater number of international conflicts will consider the necessity of allowing for a state of exception. This may be because previous conflict between states leads to an expectation of future conflict, or because a culture of conflict drives both past and future disputes. Such thinking is evident in the process leading to the French Constitution of 1958. Spurred on by the memory of the hardships of World War I and World War II, the constitutional framers in France believed that the constraints on the executive had undermined his ability to enact necessary policies in the face of an external existential threat (Foyer 1988). France's constitutional process thereby granted immense power to the president in times of emergency to ensure that such calamity does not again occur. In the case of the Greek Constitution of 1975, Greece's longheld rivalry with Turkey over Cyprus demonstrated the government's consistent inability to gain the upper hand on their persistent opponent (Tsatsos 1988). Constitutional framers therefore sought strongly to enact provisions to ensure that future governments would have both the freedom and the power necessary to prosecute future disputes with Turkey. There is thus an obvious connection between a state's historical experience and its willingness to institute provisions for a state of exception. 


\section{States of Emergency and Executive Empowerment}

The experiences that lead states to enact provisions for a state of emergency also inform how dramatically the traditional order can be reshaped by said provisions. Each emergency provision highlights the extraordinary nature of the threat to the democratic order and national survival. The Serbian Constitution of 2006 allows the declaration of a state of emergency "when the survival of the state or its citizens is threatened by a public danger (Article 200)." The Paraguayan Constitution of 1992 calls for the declaration of a state of exception in "the case of an armed international conflict, formally declared or not, or of a grave internal commotion that puts in imminent danger the rule of this Constitution or the regular functioning of the organs created by it (Article 288)."

Importantly, however, the causes of such an extraordinary threat can vary widely. When defining a period of crisis that may result in a state of emergency, nearly every emergency provision covers an external opponent, while just $56 \%$ provide measures to combat an internal threat. ${ }^{4}$ This suggests that emergency power design heavily reflects the insecurity of the international system. Some emergency provisions only allow extraordinary action following an attack by a foreign entity, but this is relatively uncommon - only $15 \%$ of states restrict the use of emergency powers in this fashion.

In fact, emergency provisions more often do not specify what actions short of open warfare warrant the declaration of a state of emergency. The Indian Constitutional Amendment of 1978 serves as a primary example, stating, "A Proclamation of Emergency declaring that the security of India or any part of the territory thereof is threatened by war or by external aggression or by armed rebellion may be made before the actual occurrence of war or of any such aggression or rebellion, if the President is satisfied that there is imminent danger thereof (Article 37, Amendment of Article 352)." A looming threat can be grounds for a declaration of a state of emergency, before an internal or external opponent even initiates

\footnotetext{
${ }^{4}$ Descriptive statistics on emergency powers come from Rooney (2019).
} 
military action. This type of fluidity introduces one potential source of danger regarding states of emergency.

Emergency provisions often delineate clear procedural tools that the executive may utilize in times of crisis, many of which stretch into the normal workings of government. The Honduran Constitution of 1982 states that the executive may "incur loans, change the purpose of an authorized item, or open additional credits for satisfying urgent or unforeseen needs in the event of war, internal disturbance or public disaster" (Article 365)." However, there is significant variation in the extent of the leader's political power during times of emergency. In $12 \%$ of emergency provisions, the leader may only declare a state of emergency, but possesses no further power. When emergency provisions do divert power to the leader, said power can face a multitude of limitations or checks. In $12 \%$ of cases the leader's power is purely restrictive - the leader has the ability to suspend certain rights or civil liberties to combat the threat. In several of the remaining cases, the executive can direct national policy, but only subject to a number of checks on their power. Under the current Constitution of the Philippines, the President may, for a limited time, direct the nation's policy during a state of emergency, but only after the Congress has declared an emergency via a two-thirds vote, if the Congress votes to authorize the emergency measures, and subject to any restrictions that the Congress deems necessary (Constitution of the Philippines, 1987, Section 23 Articles 1-2).

However, many emergency provisions dramatically alter the political landscape through granting the leader broad, sweeping power. The Taiwanese Constitution of 1994 states that during a period of emergency the President may "take all necessary measures to avert imminent danger affecting the security of the State or of the people or to cope with any serious financial or economic crisis (Article 4)," granting broad powers to combat a broad array of ills. Often emergency provisions grant the executive the ability to make declarations of policy that immediately become law. The Slovenian Constitution of 1991 grants the government 
the ability to "issue decrees with the force of law (Article 108)" during a state of emergency or war. Nearly $40 \%$ of emergency provisions grant this level of policy power. Further, only $55 \%$ of emergency provisions mandate that emergencies terminate within a specific time frame. Often emergencies can be renewed when exigencies demand it, which means nations may operate under a state of emergency well past the period of the initial crisis. ${ }^{5}$ This is the second point of danger in allowing for the state of exception.

The invocation of emergency provisions varies dramatically but can reach great frequency. While India has declared a state of emergency just three times, the use of Necessity and Urgency Decrees in Argentina reached an average of 54.5 decrees per year during the presidency of Carlos Menem, 36.5 decrees per year during the two years of Fernando de la Rua's presidency, and 60 decrees per year under Nestor Kirchner (Capriata 2008). ${ }^{6}$ Such frequent use of a state of exception has perhaps rendered their presence non-threatening to the democratic process in Argentina. Repeated use of these states of emergency were instead evidence of democratic decline in the Philippines. In 2001, President Gloria Macapagal-Arroyo declared a state of exception following protests in response to the arrest of former President Joseph Estrada, a tool she would use again in 2003, 2006, and 2009. However, as the case of Turkey suggests, given the inherent ambiguity in many emergency provisions, even one declared state of emergency can have a dramatic impact on the likelihood a democracy experiences a spell of autocracy.

\section{Emergency Powers and Autocratization: State of the Art}

Recent democratic setbacks in a variety of countries - Hungary, Brazil, Poland, Turkey,

\footnotetext{
${ }^{5}$ The case of India following the Indo-Pakistani War of 1971 highlights this fact well (Omar 2002).

${ }^{6}$ This variation occurs for two reasons. First, states have varying formal circumstances in which emergency provisions can be invoked. Second, the events that lead to invocation are not distributed evenly among states. Some states are simply more likely to encounter international foes, terrorist violence, domestic disturbances, or natural disasters.
} 
Russia to name only a few - have sparked a new generation of studies on autocratization. It seems that we are witnessing the early stages of a global reversal in democratization (Bermeo 2016, Diamond 2015, Kurlantzick 2013, Levitsky \& Ziblatt 2018, Mechkova, Lührmann \& Lindberg 2017). Contemporary autocratization is an often gradual, protracted process led by incumbent political elites (Bermeo 2016, Diamond 2015, Coppedge 2017, Lührmann, Mechkova, Dahlum, Maxwell, Olin, Petrarca, Sigman, Wilson \& Lindberg 2018, Mechkova, Lührmann \& Lindberg 2017, Runciman 2018). As Svolik (2015) points out, such autogolpes - "transitions to authoritarianism caused by the incumbent chief executive" (Przeworski, Alvarez, Cheibub \& Limongi 2000, 21) - even occur in mature democracies. Coppedge (2017) identified the gradual concentration of executive power as a key pattern of contemporary autocratization. This form of executive aggrandizement, in which elected executives weaken checks on executive power one by one, undertaking a series of institutional changes that hamper the power of opposition forces to challenge executive preferences (Bermeo 2016: 10), has become more prominent than sudden regime change. Incumbent elites are substituting highly visible methods, such as military coups and electoral fraud, with more clandestine tactics like harassment of media, repression of the opposition, and the general subversion of horizontal accountability mechanisms (Lhrmann et al. 2018).

Case studies provide some insights that states of emergency have helped to break down democracies or orchestrate further retraction in autocracies for instance in Latin America (Loveman 1993, Wright 2015), Asia (Ramraj \& Thiruvengadam 2009), Egypt (Reza 2007), Ethiopia (Toggia 2008) and Turkey (Göztepe 2018). To our knowledge, no prior comparative study exists on how incumbents use states of emergencies to foster autocratization. Most studies on emergency powers do not include systematic comparisons of de-facto effects (for a seminal example see Gross \& Aoláin (2006)). The classical work on emergency powers in the field of legal and philosophical studies emphasized the danger of 'constitutional dictatorships' turning 'unconstitutional' when leaders abused their powers to undermine democratic 
institutions (Watkins 1940, Rossiter 1948, Friedrich 1950) a debate that has been revived in recent years (Ackerman 2003, Agamben 2005, Dyzenhaus 2006, Lemke 2018).

The extant quantitative research on this topic remains underdeveloped. Studies investigating the effect of de-jure provisions for emergency powers on de-facto human rights protections provide mixed results (Davenport 1996, Keith \& Poe 2004). Their mixed findings are not surprising, as de-jure provisions can only have an effect on the human rights if they are de-facto implemented. Indeed, Hafner-Burton, Helfer \& Fariss (2011) examine how human rights treaties often allow derogations from civil liberty protections during periods of emergency. Prior studies have compared the effects of de-facto declarations of state of emergencies: Richards \& Clay (2012) show that governments are more likely to violate fundamental human rights during states of emergencies; Neumayer (2013) shows that this relationship only applies for autocracies, to a lesser extent for hybrid regime and not at all for democracies.

Recent work, for example Bjørnskov \& Voigt (2018a), helps explain why political elites might introduce emergency powers into constitutions, or why political elites declare emergencies Bjørnskov \& Voigt (2018b). Furthermore, Rooney (2019) provides a measure of the power granted to the leader during a state of exception, and shows that democratic leaders with strong constitutional emergency powers are more prone to engage in armed conflict. However these recent empirical advances have not yet been applied to a full consideration of the effects of states of emergency on autocratization.

\section{Theory: How states of emergency are linked to autoc- ratization}

States of emergency provide an opportunity structure for leaders to subvert democratic rule as it reduces the costs associated with such actions. In normal times, the expansion of executive power - particularly if done rapidly - is risky for leaders. In periods of emergency, 
the expansion of executive power is expected. States of emergency allow to the leader to combat an immediate threat to the nation by making use of previously unavailable powers. This, by itself, need not erode democracy. If the use of powers is constrained to truly existential threats to the nation, and the state returns to its standard institutions after the emergency subsides, the state of emergency has performed its function well, and democracy remained unchallenged. However, as we have described, under the state of emergency, leaders have the opportunity to both extend their control past the realm of the emergency and even past the duration of the emergency.

Thus, states of emergency are an ideal tool to undermine democracy under the disguise of democratic and constitutional legitimacy. Prior research clearly shows that most democracies erode slowly in recent decades. In a day and age where multi-party elections have become the global norm, even dictators invest a lot in appearing as democratic as possible (Bermeo 2016, Lührmann \& Lindberg 2018). Sudden moves towards autocracy - such as military coups risk to trigger mass uprisings or international interventions. Thus, wanna-be dictators rather manipulate elections and gradually expand their power.

A state of emergency not only gives leaders the opportunity to do so, but also a good argument for why they need more power. Why should they have to bother with human rights and legislative or other institutional constraints while the country is under attack? Thus, states of emergencies can help to dismantle democracy and subvert resistance to its demise. The opposition can easily be labeled as unpatriotic for challenging the government at a time when the state is imperiled and unity is required. Such proclamations were made by Indira Ghandi's government after it declared a state of emergency in 1971 in response to war with Pakistan but allowed emergency conditions to persist well after the war had ended.

Gaining more power over state resources is a key reason why incumbents push their country towards autocracy (Bermeo 2016). For instance, the Peruvian president Fujimori decided to dissolve the parliament in 1992 and assume dictatorial powers out of frustration 
about the need to compromise with other actors under democratic rule (Bermeo 2003). Two different sets of constraints on incumbents are common in democracies a modern public administration and accountability relationships . First, a modern public administration the rule of law and an impartial public administration - limits incumbents access to state resources (Merkel 2010). Thus, even though they have reached the most powerful state office, incumbents cannot arbitrarily use state resources for their personal ends or without following a prescribed set of procedures. Second, various accountability relationships constrain the power of elected officials in democracies. It is common to distinguish between vertical (related to elections and political parties), horizontal (checks and balances between institutions), and diagonal (media and civil society) dimensions of accountability (Mechkova, Lührmann \& Lindberg 2017). States of emergency can help leaders to subvert such constraints.

At the same time, states of emergency are more likely to be declared in times of political instability, which also has the potential to enhance the likelihood of democratic erosion. If, during a period of instability, a leader declares an emergency to combat the instability and in doing so constrains the freedom of action of the opposition, this will likely be seen as an important derogation from democracy by the opposition and perhaps the public. The opposition may then feel free to take extra-democratic measures as well. If the opposition does take power, they have little incentive to return to the old rules of democracy in their attempts to solidify control of the nation. When President of Madagascar Didier Ratsiraka declared a state of emergency following protests challenging the state's 2001 election results, the subsequent struggle led to a derogation from democracy that persisted even when the opposition had taken office.

In sum, authoritarian-leaning chief executives in democracies should both be more likely to declare a state of emergency, reach power during a state of emergency and, once it is declared, abuse the powers it grants to dismantle democratic institutions. Therefore, we expect states of emergency to be associated with a heightened risk of autocratization - substantial 
declines in democratic regime attributes.

\section{Research Design and Data}

Dependent variable: Autocratization year

To capture the often-gradual process of autocratization, we use V-Dems Electoral Democracy Index (EDI), which measures the extent to which a regime achieves the core institutional requirements in Dahls $(1971,1998)$ conceptualization of electoral democracy as polyarchy. The EDI runs on a continuous scale from zero to one, with higher values indicating a more democratic regime. Following Lhrmann and Lindberg (2018), we define autocratization episodes as a substantial decline (a decrease of 0.1 or more) in a countrys EDI score within one year or cumulative across consecutive period. ${ }^{7}$ A potential autocratization episode starts with a decline in the EDI of 0.01 points or more from one year to the next. It continues in the next year if the EDI declines further or if it remains stagnate for no more than three consecutive years. A potential episode ends on the fourth year of stagnation or if the EDI increases by 0.02 or more. In order to identify whether or not a country qualified as a democracy, we use the Regimes of the World measure (Lührmann, Tannenberg \& Lindberg 2018). There were 54 autocratization episodes in the V-Dem sample of democracies from 1974 to 2016 (roughly $6 \%$ of all county-year observations).

Independent variable: States of emergency

We use data on declared states of emergency from Hafner-Burton, Helfer and Fariss (2011). They have coded a binary variable on whether or not a country was in a state of emergency based on the State Department's annual human rights reports for 1974 to 2006. ${ }^{8}$. We have updated their data for 2007-2016 based on the same source and for the United

\footnotetext{
${ }^{7} \mathrm{~A}$ change of $10 \%$ is an intuitive choice for a cut-off point on a continuous, zero to one index. It is demanding enough to minimize the risk of measurement error or minor changes are driving the results. At the same time, it is low enough to capture incremental changes that do not amount to a full breakdown. For more details, see Lhrmann and Lindberg 2018).

${ }^{8}$ https://www.state.gov/j/drl/rls/hrrpt/humanrightsreport/
} 
States we used data from the Brennan Center for Justice.

Over the last 40 years, most (63\%) democracies were in a state of emergency at least once. From 1974 to 2016, 8.3\% of states of emergencies coincide with a period of substantial autocratization, while such episodes occur in just $5.2 \%$ of years without a state of emergency. This comprises $21.7 \%$ of the years with democratic decline in our sample. In most cases, such autocratization periods are lethal for democracies. $86 \%$ of democracies collapsed during an autocratization episode with a state of emergency and only $14 \%$ survived.

\section{Control variables}

We first control for the strength of the emergency powers given to the leader during a state of emergency. This allows us to test for the danger of the institutional mechanism of a state of emergency as such rather than the specific powers granted therein. We take this variable from Rooney (2019). ${ }^{9}$ and the measure captures such variation as the breadth of declaration, the existence, scope, and depth of policy powers, as well as limitations on powers via institutional oversight and the expiration of the policies and powers taken during the crisis. We include both this variable and its square, to account for the possibility that the effect of stronger emergency powers dissipates.

We expect the risk of autocratization onset to decrease, the more liberal institutions constrain the chief executive (Lhrmann and Lindberg 2018). Therefore, we control for the level of liberal democracy in the year prior using V-Dem's Liberal Democracy Index (Coppedge, Gerring, Knutsen, Lindberg, Skaaning, Teorell, Altman, Bernhard, Fish, Cornell, Dahlum, Gjerløw, Glynn, Hicken, Krusell, Lührmann, Marquardt, McMann, Mechkova, Medzihorsky, Olin, Paxton, Pemstein, Pernes, von Römer, Seim, Sigman, Staton, Stepanova, Sundström, Tzelgov, Wang, Wig, Wilson \& Ziblatt 2018, Coppedge, Gerring, Knutsen, Lindberg, Skaaning, Teorell, Altman, Bernhard, Cornell, Fish, Gjerløw, Glynn, Hicken, Krusell, Lührmann, Marquardt, McMann, Mechkova, Olin, Paxton, Pemstein, Seim, Sigman, Staton, Sundström,

\footnotetext{
${ }^{9}$ See the cited work for a full description of the procedure for calculating this measure.
} 
Tzelgov, Uberti, Wang, Wig \& Ziblatt 2018, Pemstein, Marquardt, Tzelgov, Wang, Krusell \& Miri 2017). This continuous index captures both electoral and liberal aspects of democracy such as the rule of law, legislative an judicial constraints on the executive $(0=$ not democratic; $1=$ fully democratic).

As most researchers believe economic variables are connected to autocratization (Haggard \& Kaufman 2016), we control for GDP per capita. The data on GDP per capita levels and GDP per capita growth come from the Maddison project (Maddison 2013). A variable on economic gains from oil production is also controlled for, as a common theory states a negative relationship between an oil-based economy and democracy (Ross 2001). We take this data from the Quality of Government project (Rothstein \& Teorell 2008). Some scholars link globalization to dissatisfaction with democracy and thus an increased risk of autocratization (Crouch 2004). Data on globalization comes from the Konjunkturforschungsstelle (KOF) globalization dataset (Konjunkturforschungsstelle 2011), and runs from 0 to 100 with high values indicating more globalization. A high level of political corruption might also affect satisfaction with democracy (Diamond 2008). We control for this factor with an index from the V-Dem project (Coppedge et al. 2018a; Coppedge et al. 2018b, Pemstein et al. 2018), with 0 indicating low levels of corruption and 1 high levels. Lastly, we also control for economic inequality using Gini data on disposable income from the Standardized World Income Inequality Database (SWIID) (Solt 2014), which runs from 0 to 100, with high values indicating more inequality. The literature is undecided on the direction of the relationship of economic inequality with autocratization. Inequality may bread dissatisfaction with democracy on the side of citizens; at the same time elites may feel threatened by more egalitarianism and then challenge democracy (Haggard \& Kaufman 2016).

\section{Estimation strategy}

The dichotomous nature of our dependent variable the occurrence of an autocratization episode in a given year, requires that we use probit models to evaluate our proposed hypoth- 
esis. We utilize probit models rather than alternative dichotomous variable models given the ability of the probit to account for both non-constant variance in our error and given the lack of extremity in the distribution of our independent variables. To account for potential endogeneity concerns, we lag all independent variables one year. This does not apply for the variables on emergencies, because we are specifically interested in how the declaration of a state of emergency relates to autocratization in a given year. Finally, to help reduce the bias in our standard errors, we use jackknife resampling methods in their calculation.

\section{Results and Discussion}

To reiterate, we expect the occurrence of a state of emergency to be positively correlated with the occurrence of autocratization episodes. Model 1 fits the bivariate relationship and shows - as expected - a positive and statistically significant relationship. Model 2 adds the confounders discussed above. The focal relationship remains strong and statistically significant. The predicted probability of an autocratization episode is .0396 without a declared state of emergency and .0629 with one in place (Figure 1). Thus, with a state of emergency countries are $59 \%$ more likely to decline than without a state of emergency.

Most confounders show the expected relationships. Emergency powers demonstrate the posited curvilinear relationship with autocratization. Increasing emergency powers increases the likelihood of autocratization until shortly after the mean level of emergency power strength, at which point the effect dissipates before becoming insignificant. Autocratization episodes are less likely to occur the more democratic a country is, the more it grows and prospers economically and the less oil rents a country has. Income inequality is associated with a lower risk of autocratization, which supports the idea that right-leaning elites may lead autocratization efforts in more egalitarian societies. Furthermore, a higher level of political corruption is associated with a decreased risk of autocratization. This runs counter to expectations and needs to be explored more in future research. 
Table 1: Analyses of the Effect of States of Emergency on Autocratization Autocratization Episode Autocratization Episode

\begin{tabular}{|c|c|c|}
\hline & Autocratization Episode & Autocratization Episode \\
\hline & (1) & $(2)$ \\
\hline Declared SOE & $\begin{array}{c}0.384^{* * * *} \\
(0.107)\end{array}$ & $\begin{array}{c}0.347^{* *} \\
(0.174)\end{array}$ \\
\hline Emergency Powers & & $\begin{array}{c}1.162^{* * *} \\
(0.205)\end{array}$ \\
\hline Emergency Powers (Squared) & & $\begin{array}{c}-1.362^{* * *} \\
(0.199)\end{array}$ \\
\hline Liberal Democracy Index & & $\begin{array}{c}-3.310^{* * * *} \\
(0.903)\end{array}$ \\
\hline Political Corruption Index & & $\begin{array}{c}-1.138^{* *} \\
(0.508)\end{array}$ \\
\hline Gini Inequality Index (Disposable Income) & & $\begin{array}{c}-0.038^{* * * *} \\
(0.011)\end{array}$ \\
\hline Real GDPPC & & $\begin{array}{c}-0.779^{* * * *} \\
(0.174)\end{array}$ \\
\hline GDPPC Growth & & $\begin{array}{c}-5.689^{* * * *} \\
(1.978)\end{array}$ \\
\hline Oil Rents & & $\begin{array}{c}0.111^{* * *} \\
(0.019)\end{array}$ \\
\hline KOF Globalisation Index & & $\begin{array}{c}0.022 \\
(0.016)\end{array}$ \\
\hline Constant & $\begin{array}{c}-72.452^{* * *} \\
(10.387)\end{array}$ & $\begin{array}{c}-186.004^{* * *} \\
(27.419)\end{array}$ \\
\hline $\mathrm{N}$ & 2668 & 2028 \\
\hline
\end{tabular}

Notes: Jackknife standard errors in parentheses. All controls are lagged by one year. ${ }^{*} p<0.10,{ }^{* *} p<0.05,{ }^{* * *} p<.01$

Figure 1: States of Emergency and Autocratization

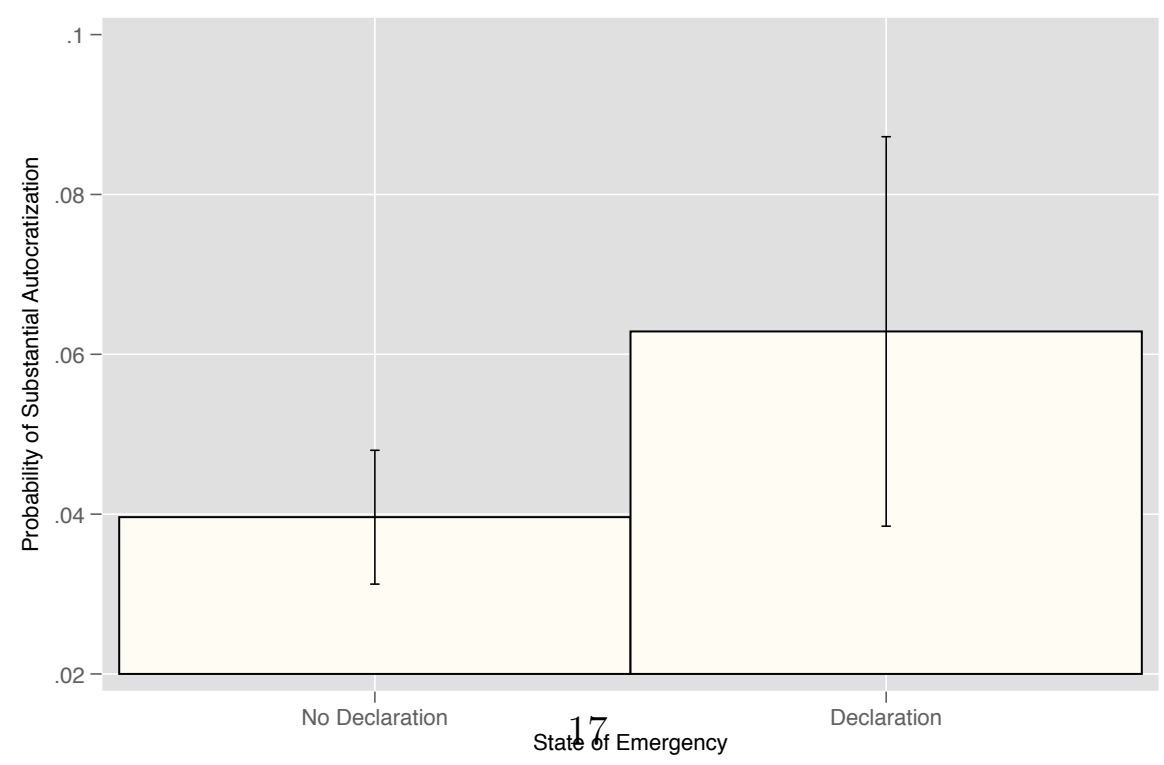




\section{Robustness}

For robustness purposes, we estimate Model 2 with year-fixed effects (see Table 2 in the appendix). Findings holds even when looking solely at variance within years. ${ }^{10}$ We also estimate a model using a different dependent variable: the change in the V-Dem Electoral Democracy Index (EDI) in the year of a declaration of the state of emergency compared to the year prior (see Table 3 in the appendix). Findings hold; a declaration of a state of emergency is associated with a statistically significant decline in the EDI.

\section{Conclusions}

Autocratization episodes - a substantial decline of democratic regime attributes - are almost $60 \%$ more likely to occur in years with declared states of emergency. This finding is robust to a number of different statistical tests and model specifications. States of emergency present an opportunity structure for leaders to dismantle democratic institutions and resistance to autocratization. As such they are not necessarily a trigger or cause of autocratization or even democratic breakdown. States of emergency are more likely to be declared once a country is in crisis (e.g. Moldova in 1992) or by political leader who aims to circumvent democratic constraints (e.g. Trump in 2019; Chavez in Venezuela in 1999). In other cases - such as Turkey - states of emergency were declared as autocratization was well under way already and were instrumental for the regime to accelerate the process. Thus, we suggest to think of states of emergency as a potential symptom and accelerator of autocratization processes. Like a fever, they are a strong warning sign that something maybe wrong with the state of democracy and that autocratization might be under the way.

Consequently, the public should examine each declaration of a state of emergency with care. Observers should scrutinize the intend of the leader, how severe the situation declared to be an emergency really is and the subsequent use or abuse of the extraordinary powers.

\footnotetext{
${ }^{10} \mathrm{~A}$ model containing country-fixed effects drops too many observations for estimation to be valid.
} 
Fortunately, this is what happened in the United States after the declaration of a state of emergency by Donald Trump in February 2019. As noted, 58 ex-senior security officials issued a joint letter criticizing his move. ${ }^{11}$ His strategy also faces legal and congressional hurdles. ${ }^{12}$ Our research shows that the scepticism towards his approach is warranted. Trumps decision to declare a state of emergency with the main objective of circumventing legal constraints has put the United States into the bad company of eroding democracies and opens the door for further democratic declines. Such an abuse of emergency powers should be met with resistance.

This initial systematic look at the evidence suggests that states of emergency are both a cause and consequence of democratic decay. This should serve as the launching point for additional investigations of this relationship. Future research should seek to shed more light on the conditions under which states of emergency may contribute to autocratization, and what characteristics of emergencies indicate that democracy is particularly in peril. Further, this research must also examine which types of emergency provisions are more likely to help preserve democracy, and which types are instead likely to see democracy meet its demise.

\footnotetext{
${ }^{11}$ http://cdn.cnn.com/cnn/2019/images/02/25/2019-2-21.final.national.emergency.decl.pdf

${ }^{12}$ https://www.washingtonpost.com/powerpost/house-sponsor-of-resolution-to-nix-emergencydeclaration-acknowledges-uphill-battle-on-overriding-expected-trump-veto/2019/02/26/22104532-39d211e9-aaae-69364b2ed137 story.html
} 


\section{References}

Ackerman, Bruce. 2003. "The emergency constitution." Yale lJ 113:1029.

Agamben, Giorgio. 2005. State of exception. Vol. 2 University of Chicago Press.

Bermeo, Nancy. 2003. Ordinary people in extraordinary times - The citizenry and the breakdown of democracy. Princeton, NJ: Princeton University Press.

Bermeo, Nancy. 2016. "On democratic backsliding." Journal of Democracy 27(1):5-19.

Bjørnskov, Christian \& Stefan Voigt. 2018a. "The architecture of emergency constitutions." International Journal of Constitutional Law 16(1):101-127.

Bjørnskov, Christian \& Stefan Voigt. 2018b. "Why do governments call a state of emergency? On the determinants of using emergency constitutions." European Journal of Political Economy 54:110-123.

Capriata, Laura. 2008. "Kirchner firmó cada seis días un decreto de necesidad y urgencia." $L a$ Nacion http://www.lanacion.com.ar/1003971-kirchner-firmo-cada-seis-dias-un-decretode-necesidad-y-urgencia.

Coppedge, M., J. Gerring, C. H. Knutsen, S. I. Lindberg, S-E. Skaaning, J. Teorell, D. Altman, M. Bernhard, A. Cornell, M. S. Fish, H. Gjerløw, A. Glynn, A. Hicken, J. Krusell, A. Lührmann, K. L. Marquardt, K. McMann, V. Mechkova, M. Olin, P. Paxton, D. Pemstein, B. Seim, R. Sigman, J. Staton, A. Sundström, E. Tzelgov, L. Uberti, Y. Wang, T. Wig \& D. Ziblatt. 2018. "V-Dem Codebook v8." Varieties of Democracy (V-Dem) Project.

Coppedge, M., J. Gerring, C. H. Knutsen, S. I. Lindberg, S-E. Skaaning, J. Teorell, D. Altman, M. Bernhard, M. S. Fish, A. Cornell, S. Dahlum, H. Gjerløw, A. Glynn, A. Hicken, J. Krusell, A. Lührmann, K. L. Marquardt, K. McMann, V. Mechkova, J. Medzihorsky, M. Olin, P. Paxton, D. Pemstein, J. Pernes, J. von Römer, B. Seim, R. Sigman, J. Staton, N. Stepanova, A. Sundström, E. Tzelgov, Y. Wang, T. Wig, S. Wilson \& D. Ziblatt. 2018. "V-Dem Dataset v8." Varieties of Democracy (V-Dem) Institute .

Coppedge, Michael. 2017. "Eroding regimes: What, where, and when?" Varieties of Democracy (V-Dem) Institute Working paper.

Crouch, Colin. 2004. Post-democracy. Polity Cambridge.

Cunningham, Erin \& Hugh Naylor. 2016. "Turkish authorities granted emergency powers amid 'cleansing' after failed coup." Washington Post .

Davenport, Christian A. 1996. "” Constitutional Promises" and Repressive Reality: A CrossNational Time-Series Investigation of Why Political and Civil Liberties are Suppressed." The Journal of Politics 58(3):627-654. 
Diamond, Larry. 2008. "The democratic rollback." Foreign Affairs 87(2):36-48.

Diamond, Larry. 2015. "Facing up to the democratic recession." Journal of Democracy 26(1):141-155.

Dyzenhaus, David. 2006. The constitution of law: Legality in a time of emergency. Cambridge University Press.

Esen, Berk \& Sebnem Gumuscu. 2017. "Turkey: How the Coup Failed." Journal of Democracy 28(1):59-73.

Ferejohn, John \& Pasquale Pasquino. 2004. "Law of Exception: A Typology of Emergency Powers, The." Int'l J. Const. L. 2:210.

Foyer, Jean. 1988. The Drafting of the French Constitution of 1958. In Constitution Makers on Constitution Making, ed. Robert A Goldwin \& Art Kaufman. American Enterprise Institute.

Friedrich, Carl J. 1950. "Military government and dictatorship." The Annals of the American Academy of Political and Social Science 267(1):1-7.

Göztepe, Ece. 2018. "The permanency of the state of emergency in Turkey." Zeitschrift für Politikwissenschaft 28(4):521-534.

Gross, Oren \& Fionnuala Ní Aoláin. 2006. Law in times of crisis: emergency powers in theory and practice. Vol. 46 Cambridge University Press.

Hafner-Burton, Emilie M, Laurence R Helfer \& Christopher J Fariss. 2011. "Emergency and escape: explaining derogations from human rights treaties." International Organization 65(04):673-707.

Haggard, Stephan \& Robert R. Kaufman. 2016. Dictators and democrats - Masses, elites and regime change. Princeton, NJ: Princeton University Press.

Keith, Linda Camp \& Steven C Poe. 2004. "Are Constitutional State of Emergency Clauses Effective-An Empirical Exploration." Hum. Rts. Q. 26:1071.

Kingsley, Patrick. 2017. "Turkish leader extends nation's state of emergency." The Boston Globe .

Konjunkturforschungsstelle, Kof. 2011. "KOF Index of Globalization." URL:; http://globalization. kof. ethz. ch/\& Consultado el 12.

Kurlantzick, Joshua. 2013. Democracy in retreat: The revolt of the middle class and the worldwide decline of representative government. New Haven, Conneticut: Yale University Press. 
Lemke, Matthias. 2018. "What does state of exception mean?" Zeitschrift für Politikwissenschaft 28(4):373-383.

Levitsky, Steven \& Daniel Ziblatt. 2018. How democracies die. London: Viking, an imprint of Penguin Books.

Loveman, Brian. 1993. The constitution of tyranny: regimes of exception in Spanish America. Univ of Pittsburgh Pr.

Lowen, Mark. 2016. "Turkey coup attempt: State of emergency announced." BBC News .

Lührmann, Anna, Marcus Tannenberg \& Staffan I. Lindberg. 2018. "Regimes of the world (RoW): Opening new avenues for the comparative study of political regimes." Politics and Governance 6(1):60-78.

Lührmann, Anna \& Staffan II Lindberg. 2018. "Keeping the Democratic Façade: Contemporary Autocratization as a Game of Deception." V-Dem Working Paper 75.

Lührmann, Anna, Valeriya Mechkova, Sirianne Dahlum, Laura Maxwell, Moa Olin, Constanza Sanhueza Petrarca, Rachel Sigman, Matthew C. Wilson \& Staffan I. Lindberg. 2018. "State of the world 2017: Autocratization and exclusion?" Democratization 25(8):1321-1340.

Maddison, Angus. 2013. "The Maddison-Project." línea] http://www. ggdc. net/maddison/maddison-project/home. htm 1:14.

Manrique, Gustavo Planchart. 1988. The Making of the Venezuelan Constitution. In Constitution Makers on Constitution Making, ed. Robert A Goldwin \& Art Kaufman. American Enterprise Institute.

Mechkova, Valeriya, Anna Lührmann \& Staffan I. Lindberg. 2017. "How much democratic backsliding?" Journal of Democracy 28(4):162-169.

Merkel, Wolfgang. 2010. "Are dictatorships returning? Revisitin the 'democratic rollback' hypothesis." Contemporary Politics 16(1):17-31.

Neumayer, Eric. 2013. "Do governments mean business when they derogate? Human rights violations during notified states of emergency." The Review of International Organizations 8(1):1-31.

Omar, Imtiaz. 2002. Emergency powers and the courts in India and Pakistan. Vol. 53 Martinus Nijhoff Publishers.

Pemstein, D., K. L. Marquardt, E. Tzelgov, Y. Wang, J. Krusell \& F. Miri. 2017. "The VDem measurement model: Latent variable analysis for cross-national and cross-temporal expert-coded data.". 
Przeworski, Adam, Michael E. Alvarez, José Antonio Cheibub \& Fernando Limongi. 2000. Democracy and Development: Political Institutions and Well-Being in the World, 19501990. Cambridge: Cambridge University Press.

Ramraj, Victor V \& Arun K Thiruvengadam. 2009. Emergency powers in Asia: exploring the limits of legality. Cambridge University Press.

Reza, Sadiq. 2007. "Endless emergency: The case of Egypt." New Criminal Law Review: In International and Interdisciplinary Journal 10(4):532-553.

Richards, David L \& K Chad Clay. 2012. "An umbrella with holes: Respect for non-derogable human rights during declared states of emergency, 1996-2004." Human Rights Review $13(4): 443-471$.

Rooney, Bryan. 2019. "Emergency Powers in Democracies and International Conflict." Journal of Conflict Resolution .

URL: https://doi.org/10.1177/0022002718755251

Ross, Michael L. 2001. "Does oil hinder democracy?" World politics 53(3):325-361.

Rossiter, Clinton. 1948. Constitutional dictatorship. Transaction Publishers.

Rothstein, Bo O \& Jan AN Teorell. 2008. "What is quality of government? A theory of impartial government institutions." Governance 21(2):165-190.

Runciman, David. 2018. How democracy ends. London: Profile Books.

Solt, Frederick. 2014. "The Standardized World Income Inequality Database (SWIID).".

Svolik, Milan W. 2015. "Which democracies will last? Coups, incumbent takeovers and the dynamic of democratic consolidation." British Journal of Political Science 45(4):715738.

Toggia, Pietro S. 2008. "The state of emergency: police and carceral regimes in modern Ethiopia." Journal of Developing Societies 24(2):107-124.

Tsatsos, Constantine. 1988. Making the Constitution of Greece. In Constitution Makers on Constitution Making, ed. Robert A Goldwin \& Art Kaufman. American Enterprise Institute.

Watkins, Frederick M. 1940. "The problem of constitutional dictatorship." Public Policy $1: 324-379$.

Wright, Claire. 2015. Emergency Politics in the Third Wave of Democracy: A Study of Regimes of Exception in Bolivia, Ecuador, and Peru. Lexington Books. 


\section{Appendix}

Table 2: Analyses of the Effect of States of Emergency on Autocratization

\begin{tabular}{|c|c|c|}
\hline & Autocratization Episode & Autocratization Episode \\
\hline & (1) & $(2)$ \\
\hline Declared SOE & $0.487^{* * *}$ & $0.392^{* *}$ \\
\hline & $(0.110)$ & $(0.163)$ \\
\hline Emergency Powers & & $1.188^{* * *}$ \\
\hline & & $(0.212)$ \\
\hline Emergency Powers (Squared) & & $-1.382^{* * *}$ \\
\hline & & $(0.209)$ \\
\hline Liberal Democracy Index & & $-3.452^{* * *}$ \\
\hline & & $(0.950)$ \\
\hline Political Corruption Index & & $-1.160^{* *}$ \\
\hline & & $(0.536)$ \\
\hline Gini Inequality Index (Disposable Income) & & $-0.038 * * *$ \\
\hline & & $(0.012)$ \\
\hline Real GDPPC & & $-0.862^{* * *}$ \\
\hline & & $(0.202)$ \\
\hline GDPPC Growth & & $-5.570 * *$ \\
\hline & & $(2.285)$ \\
\hline Oil Rents & & $0.116^{* * *}$ \\
\hline & & $(0.025)$ \\
\hline KOF Globalisation Index & & 0.030 \\
\hline & & $(0.019)$ \\
\hline Constant & $-1.147^{* * *}$ & $9.711^{* * *}$ \\
\hline & $(0.181)$ & $(1.780)$ \\
\hline $\mathrm{N}$ & 2276 & 1475 \\
\hline
\end{tabular}


Figure 2: States of Emergency and Autocratization: Fixed Effects

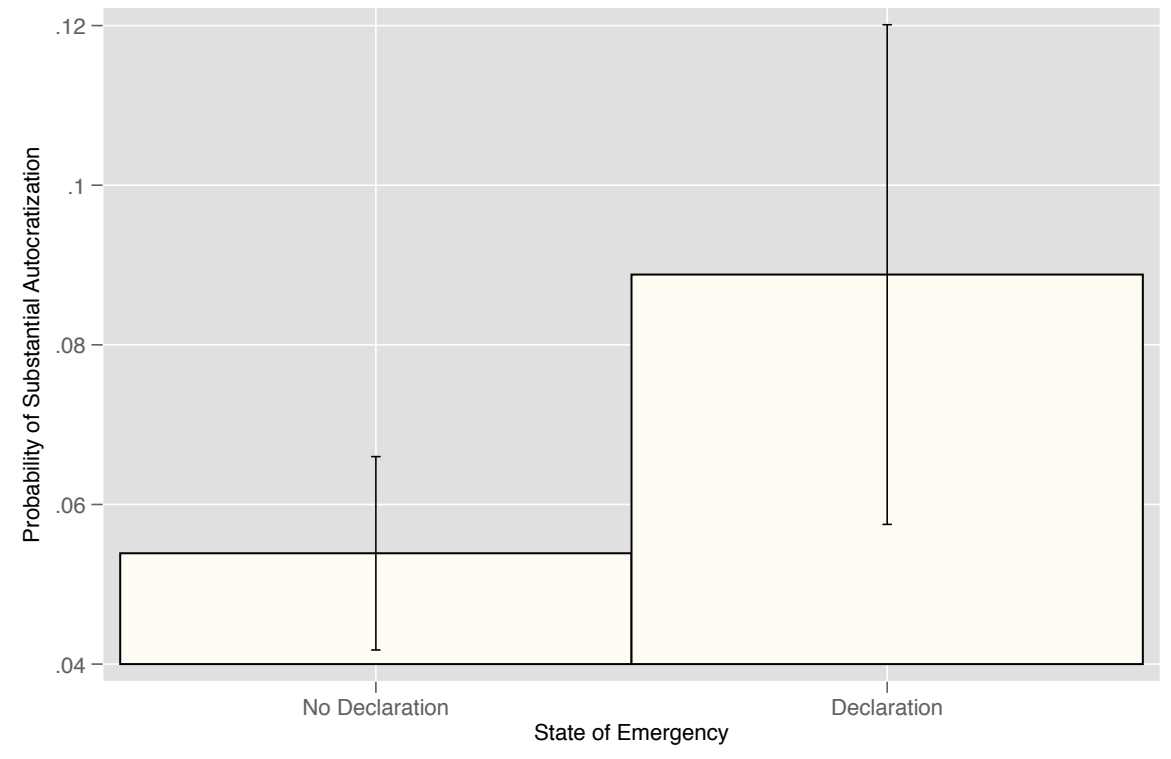


Table 3: Analyses of the Effect of States of Emergency on Electoral Democracy

\begin{tabular}{lc}
\hline & Electoral Democracy Index \\
\cline { 2 - 2 } Declared SOE & $(1)$ \\
Emergency Powers & $\left(0.006^{* * *}\right.$ \\
Emergency Powers (Squared) & $-0.003^{* *}$ \\
Liberal Democracy Index & $(0.001)$ \\
& $0.004^{* *}$ \\
Gini Inequality Index (Disposable Income) & $(0.002)$ \\
& $-0.096^{* * *}$ \\
Real GDPPC & $(0.023)$ \\
& 0.000 \\
GDPPC Growth & $(0.000)$ \\
Oil Rents & $0.010^{* * *}$ \\
KOF Globalisation Index & $(0.002)$ \\
Time & 0.009 \\
Constant & $(0.025)$ \\
& $-0.001^{* * *}$ \\
N & $(0.000)$ \\
& 0.000 \\
& $(0.000)$ \\
& $-0.001^{* * *}$ \\
& $(0.000)$ \\
& $1.290^{* * *}$ \\
& $(0.319)$ \\
\hline
\end{tabular}

Notes: Robust standard errors in parentheses. All controls are lagged by one year.

$$
{ }^{*} p<0.10,{ }^{* *} p<0.05,{ }^{* * *} p<.01
$$

